\title{
Funkcje witryn internetowych spółdzielni uczniowskich w szkołach ponadpodstawowych
}

Functions of Students" "Cooperatives" Websites in Secondary Schools

\begin{abstract}
ABSTRAKT
Celem artykułu jest ukazanie funkcji witryn internetowych spółdzielni uczniowskich w szkołach ponadpodstawowych. Przedmiotem badania uczyniono strony internetowe prowadzone przez uczniów-spółdzielców. W artykule wykorzystano jakościowq metodę badania tekstów, polegajacq na analizie treści stron internetowych 13 uczniowskich zrzeszeń spółdzielczych funkcjonujących w szkołach ponadpodstawowych.

Spółdzielnie uczniowskie należq do organizacji szkolnych, które posiadaja ponad stuletniq tradycję i ugruntowane sposoby działania. Jednak nowe technologie informacyine zmieniły możliwości funkcjonowania i komunikowania się również w tych organizacjach szkolnych, które wykorzystuja witryny internetowe w różnych celach. Na podstawie dokonanych analiz można wskazać wielorakie znaczenie witryn internetowych prowadzonych przez spółdzielnie uczniowskie w szkołach ponadpodstawowych. Ich strony internetowe pełniq funkcje informacyino-edukacyine i popularno-towarzyskie. Zawieraja
\end{abstract}

SLOWA KLUCZOWE witryny internetowe, spółdzielnie uczniowskie, szkoły ponadpodstawowe, komunikacja, uczeń, spółdzielca

\section{KEYWORDS}

websites, students' cooperatives, secondary schools, communication, student, cooperator

SPI Vol. 24, 2021/3

ISSN 2450-5358 e-ISSN 2450-5366 DOI: 10.12775/SPI.2021.3.007

Nadestano: 9.05.2021 Zaakceptowano: 29.09.2021

Raporty z badań 
informacje dotyczqce: rodzaju prowadzonej działalności gospodarczej i jej oferty, współczesnego ruchu spółdzielczego, korzyści wynikajqcych z przynależności do spółdzielni uczniowskiej, polegajacych choćby na organizacji czasu wolnego, nawiqzywaniu kontaktów młodych spółdzielców między sobq i społecznościq pozaszkolnq. Wszystko to świadczy o wzroście popularności witryn internetowych i ich edukacyinym znaczeniu.

Wyniki badań skłaniaja do postawienia następującego postulatu: w zmediatyzowanej rzeczywistości należy edukować i zachęcać uczniów do właściwego i mqqdrego korzystania z przestrzeni wirtualnej, stanowiqcej nowq przestrzeń dydaktyczno-wychowawczq, wymagajqcq odpowiedniego zagospodarowania przez wszystkie podmioty szkoły: nauczycieli, wychowawców, uczniów i ich rodziców, w tym przez organizacje uczniowskie, kłórych przykładem sq spółdzielnie uczniowskie.

\section{ABSTRACT}

The aim of the article is to show functions of students' cooperatives' websites. The subject of study are the websites being run by students' cooperatives in secondary schools. The article begins by utilizing the qualitative method of textual analysis of the content of these websites. The websites are maintained by thirteen students' cooperatives that operate in secondary schools.

The students' cooperatives belong to school organizations with more than century of tradition and have well-established working methods. However, new information technologies have changed work and communication opportunities and the school organizations also use the websites for different purposes. Within the analysis of the websites being run by students' cooperatives in the secondary schools, it is clearly discernible how and why the websites vary. The websites serve different functions ranging from the educationally informative to the popular-social. The content concerns the business activity and what it offers, current cooperative's movement, benefits of being a member of a students' cooperative, for example organizing free time, networking between young cooperatives and socializing outside of the school, that is visible within increased popularity of websites and the development of their educational dimension.

The results lead to the following postulate: in a mediatized reality, students should be educated and encouraged to make proper and wise use of virtual space, which is a new teaching and educational space 
that requires proper management by all school entities: teachers, form tutors, students and their parents, including students' organizations such as student cooperatives.

\section{Wprowadzenie}

Pierwsza spółdzielnia uczniowska ${ }^{1}$ w Polsce powstała w 1900 roku. Jej założycielką i opiekunem była Jadwiga Dziubińska (Świtalski 1985: 17). Spółdzielnia działała w formie sklepiku szkolnego. Mimo że zainteresowanie uczniów i nauczycieli oraz osób kupujących artykuły od młodych spółdzielców było duże, to popularność tej spółdzielni pozostawała w cieniu do I wojny światowej. Lata 1918-1939 były okresem rozkwitu takich organizacji szkolnych i uzyskiwania powszechnego zainteresowania, o czym pisze Elżbieta Magiera, stwierdzając, że różne podmioty (np. polski ruch spółdzielczy, władze oświatowe, związkowy ruch nauczycielski) popularyzowały i rozwijały spółdzielczość uczniowską, wskazując na jej walory dydaktyczno-wychowawcze (Magiera 2011a; 2011b: 107-123; 2014: 103-104; 2016: 183-197). Istnieją nieliczne nowe publikacje poświęcone spółdzielniom uczniowskim w okresie Polski Ludowej (np. Magiera 2019: 63-90). Opracowanie działalności spółdzielni uczniowskich w okresie po transformacji ustrojowej w Polsce nie zostało jeszcze dokonane.

Spółdzielnie uczniowskie są wartościowymi organizacjami szkolnymi, które przetrwały 121 lat i funkcjonują do dzisiaj. $\mathrm{O}$ ich istnieniu świadczą aktualne witryny internetowe zawierające rozmaite treści. Są one dostępne dzięki nowym technologiom

1 Krajowa Rada Spółdzielcza podaje definicję spółdzielni uczniowskiej jako organizacji uczniów działającej na terenie szkoły i prowadzoną przez nich samych. Członkami spółdzielni mogą być tylko uczniowie (co najmniej 10 osób), a opiekę nad nimi sprawuje wybrany przez dyrekcję nauczyciel-opiekun (https://www.krs.org.pl/index.php?option=com_content\&view=ar ticle\&id=41\&Itemid=297). Tę definicję uzupełnia Fundacja Rozwoju Spó1dzielczości Uczniowskiej, dodając, że działa na podstawie uchwalonego statutu (http://www.frsu.pl/uploads/attachments/9eb4dc8ac519e221fde3540cc66 cd6fa.pdf). Są to dwa podmioty, które sprawują pieczę nad współczesnymi spółdzielniami uczniowskimi, prowadząc swoje strony internetowe z różnorodnymi informacjami skierowanymi do osób zainteresowanych ruchem spółdzielczym w szkołach. 
informacyjno-komunikacyjnym i urządzeniom z dostępem do Internetu. To one tworzą platformę komunikacyjną, która stała się integralną częścią współczesnej rzeczywistości, oddziaływującą na dzieci i młodzież oraz dorosłych we wszystkich sferach życia. Trudno sobie wyobrazić świat bez nowoczesnej technologii, która nadaje zupełnie nowy wymiar codziennemu życiu. Internet staje się naturalnym sposobem komunikacji interpersonalnej, a jego siła oddziaływania wzrasta z każdym dniem (Sokołowski 2013: 7).

Analizie poddałam strony internetowe spółdzielni uczniowskich funkcjonujące na portalu społecznościowym Facebook oraz strony internetowe szkól, w których działają te organizacje, jak również inne witryny związane ze spółdzielniami uczniowskimi. Stosując jakościową metodę badania tekstów, oparłam się na twierdzeniu Davida Silvermana, który pisze, że jest to metoda szczególnie pożądana w sferze komunikowania masowego (Silverman 2012:149-150). Nie wymaga ona analizy większej ilości treści zamieszczanych na stronach internetowych czy portalach społecznościowych, bowiem w przypadku moich badań liczyło się poznanie i zrozumienie kategorii używanych przez uczestników życia spółdzielczego w szkołach ponadpodstawowych, a także poznanie ich w konkretnych działaniach. Badania rozpoczęłam od zapoznania się z literaturą przedmiotu i stronami internetowymi spółdzielni uczniowskich. Strony internetowe traktuję jako materiał źródłowy, który przeanalizowałam pod kątem przyjętych kategorii (informacyjno-edukacyjnej i popularno-towarzyskiej), by w końcu przystąpić do selekcji (krytyki) i porządkowania faktów. Sposobem postępowania naukowego, czyli techniką i zarazem metodą badań, była analiza jakościowa treści zamieszczanych na stronach internetowych poszczególnych spółdzielni uczniowskich (Łobocki 2009: 28-31). Analizą objęłam 20 stron internetowych należących do 13 spółdzielni uczniowskich, na które składają się: jedna strona internetowa utworzona wyłącznie dla tego zrzeszenia, 4 posiadające profil na Facebooku, 3 mające zakładkę o spółdzielni uczniowskiej na Facebooku szkoły, 7 przedstawiających działania na stronie internetowej szkoły, w której zostało zrzeszenie powołane, oraz 5 na innych witrynach w Internecie, takich jak: www.szkolnafirma.pl i www. school\&collegelistings.com. Zaznaczyć należy, że $6 \mathrm{z}$ analizowanych 
spółdzielni uczniowskich umieszcza swoje informacje na więcej niż jednej stronie internetowej ${ }^{2}$.

Strony internetowe stanowią narzędzie komunikacji, która jest fundamentem tworzenia poprawnych związków, grup i całych społeczności. Komunikacja to przekaz informacji między jednostkami lub grupami, dokonująca się za pośrednictwem języka i symboli przez nieoficjalne lub oficjalne kanały komunikacyjne. $Z$ komunikacją bezpośrednią mamy do czynienia wtedy, gdy wszyscy członkowie grupy mają możliwość swobodnego komunikowania się za sobą. Komunikacja internetowa polega na tym, że nadawca przekazu informacji i jego odbiorca porozumiewają się przez sieć komputerową (Olechnicki, Załęcki 1999: 97-98). Forma informowania o swoim istnieniu i podejmowanych działaniach poprzez Internet zaczęła zdobywać

2 Badaniami zostały objęte spółdzielnie uczniowskie używające komunikatorów internetowych, takich jak: własna strona internetowa spółdzielni uczniowskiej (1), którą posiada „Duo” w Zespole Szkół nr 2 Centrum Kształcenia Ustawicznego im. Tadeusza Kościuszki w Pyrzycach, portal społecznościowy Facebook (4) spółdzielni uczniowskich: „Modraczek” w Zespole Placówek Edukacyjnych w Olsztynie, „Winien-ma” w Zespole Szkół Hotelarsko-Turystycznych w Zakopanem, „Spółdzielnia uczniowska ZSS Stronie Śląskie” w Zespole Szkół Samorządowych w Stroniu Śląskim, „Nie ma Lipy”w Zespole Szkół im. Jana Pawła II w Lipce i Facebook placówek (3), na których mają swoje strony spółdzielnie uczniowskie: „Vzór” w Zespole Szkół Mechanicznych w Poznaniu, „Szarotka” w Zespole Szkół im. Bł. Ks. Piotra Dańkowskiego w Jordanowie, „Plastusie”, strony internetowe szkół (7), w których działają spółdzielnie uczniowskie: „Szarotka” w Zespole Szkół im. Bł. Ks. Piotra Dańkowskiego w Jordanowie, „Ekonomik” w Zespole Szkół Zawodowych im. Adama Chętnika w Ostrołęce, „Omnia” w IV Liceum Ogólnokształcącym im. Jana Pawła II w Tarnowie, „Plastusie”w Zespole Szkół Informatycznych w Słupsku, „Pychotka” w Zespole Szkół Specjalnych nr 105 w Warszawie, „Punkt Ksero ZSŁ” w Zespole Szkół Łączności im. Obrońców Poczty Polskiej w Gdańsku, „Rockefeller” w Zespole Szkół Ekonomicznych nr 2 im. I. Daszyńskiego $\mathrm{w}$ Krakowie oraz inne strony internetowe stanowiące uzupełnienie dla następujących zrzeszeń szkolnych (5): www.school\&collegelistings.com, na której „Modraczek” w Zespole Placówek Edukacyjnych w Olsztynie prowadzi lakoniczne zapiski i umieszcza zdjęcia (https://www.schoolandcollegelistings. com/XX/Unknown/904305449739092/Sp\%C3\%B3\%C5\%82dzielnia-Uczniowska--MODRAczeK), a także www.szkolnafirma.pl propagująca zakładanie spółdzielni uczniowskich i podająca przykład takich spółdzielni: „Winien-ma” w Zespole Szkół Hotelarsko-Turystycznych w Zakopanem, „Nie ma Lipy” w Zespole Szkół im. Jana Pawła II w Lipce, „Szarotka”w Zespole Szkół im. Bł. Ks. Piotra Dańkowskiego w Jordanowie, „Rockefeller”w Zespole Szkól Ekonomicznych nr 2 im. I. Daszyńskiego w Krakowie (https://szkolnafirma. $\mathrm{pl} /$ news/). 
wielu zwolenników (Aouil 2008: 26-28). Liczy się bowiem nie tylko przekaz, ale też kontakt, poczucie wspólnoty, wspólne zainteresowania i poglądy (Hyb 2012: 157). Celem umieszczania informacji na witrynach internetowych jest przekaz i wymiana informacji. Ich rodzaj i forma - w przypadku organizacji szkolnych - zależy od kreatywności młodzieży oraz od uzyskanej pomocy nauczyciela-opiekuna.

Komunikacja łączy, scala, integruje wszystkie podmioty w niej uczestniczące. Młodzież potrzebuje wyrażać swoje myśli, uczucia czy przekonania. Używa do tego symboli (emotikony) i języka, przekazując w ten sposób swoje wyjątkowe ,ja”. Może się to odbywać w różny sposób, na przykład przez słowa, dźwięki/filmy i gesty. Przekaz drogą elektroniczną następuje dużo częściej niż w kontakcie bezpośrednim z drugim człowiekiem (Bochnia, Bochnia 2010: 60-61). To atrakcyjna i dogodna forma przekazu informacji w realnej rzeczywistości, z której korzystają różne grupy społeczne, w tym adolescenci (Huk 2012: 335-353; 2014: 164-165). Młodzież wybiera komunikowanie się przez Internet ze względu na szybkość przekazu wiadomości, możliwość prowadzenia rozmów na forach z wieloma osobami jednocześnie, dostępność, nieograniczoną komunikację ze światem, zdobywanie nowych doświadczeń, podtrzymywanie znajomości, możliwość przełamania nieśmiałości, łatwość komunikacji, dobrowolność i mniejszą natarczywość tego typu komunikacji w stosunku do rozmów telefonicznych (Polak 2008: 120; Łęski, Wieczorek 2004; Izdebska 2002: 94; Morbitzer 2009: 5-7; Bębas, Plis, Bednarek 2012: 11; Adler, Rosenfeld, Proctor II 2018; Jemielniak 2019: 17).

Powyższe zalety przekazu treści przez Internet oraz przeżywany okres pandemii wskazują na potrzebę podjęcia w placówkach oświatowych alfabetyzacji uczniów i ich opiekunów (rodziców, nauczycieli, autorów książek) w obrębie wiedzy o rodzajach i działaniu komunikatorów internetowych oraz ich narzędzi. Ważne są umiejętności ich efektywnego zastosowania opierające się na zdolnościach wykraczających poza standardową bazę edukacji (pisanie, czytanie itp.). Wacław Strykowski i Wojciech Skrzydlewski wymieniają komponenty tej alfabetyzacji, do których zaliczają następujące umiejętności: korzystanie $\mathrm{z}$ komunikatorów w celu wymiany informacji, dostęp do informacji i umiejętność jej przekazywania (alfabetyzm technologiczny), pozyskiwanie, selekcjonowanie i ocenianie informacji (alfabetyzm informacyjny), budowanie komunikatów w Internecie, branie 
odpowiedzialności za swoje wpisy on-line (Strykowski, Skrzydlewski 2002: 7-8). Wymienione umiejętności są niezbędne do prowadzenia poprawnej komunikacji z użyciem komunikatorów internetowych, dlatego współczesna szkoła stara się wyposażyć uczniów i nauczycieli w takie kompetencje (Kania 2018: 7,14).

Postęp informacyjno-komunikacyjny, nazywany „trzecią rewolucją przemysłową", zmienił komunikację międzyludzką. $\mathrm{Na}$ skutek dynamicznej ekspansji technologii pojawiły się nowe sposoby przekazywania treści, które są również istotne dla organizacji uczniowskich, w tym spółdzielni szkolnych. Nowe technologie ułatwiają przekaz informacji, umożliwiają porozumiewanie się $\mathrm{w}$ grupie w każdej chwili, ale również wymagają właściwych umiejętności ich wykorzystywania. Tomasz Goban-Klas twierdzi, że wbrew niepochlebnym opiniom, nowe technologie tworzą więziotwórczą funkcję poprzez tworzenie grup dyskusyjnych (Goban-Klas 2005: 181-182).

\section{Funkcje informacyjno-edukacyjne witryn internetowych spółdzielni uczniowskich}

$\mathrm{Na}$ stronach internetowych spółdzielni uczniowskich można odnaleźć wiele treści mających doniosłe znaczenie dla praktyki pedagogicznej. Przede wszystkim spółdzielnie uczniowskie na portalu społecznościowym Facebook i własnych stronach internetowych prezentują rodzaj prowadzonej przez siebie działalności i swoją ofertę. Witryny internetowe są prowadzone przez samych członków spółdzielni uczniowskich, którzy ustalają zakres i formę przekazywania informacji.

$\mathrm{Z}$ analizowanych stron internetowych wynika, że najbardziej popularną formą działalności spółdzielczej w szkołach ponadpodstawowych jest sklepik szkolny. Jego prowadzenie wybrało siedem spółdzielni uczniowskich: „Szarotka” w Zespole Szkół im. Bł. Ks. Piotra Dańkowskiego w Jordanowie (por. http://zsdjordanow.iap.p1/spoldzielnia-uczniowska-szarotka/aktualnosci-1; https://szkolnafirma. $\mathrm{pl} /$ news/spoldzielnia-uczniowska-szarotka-dzialajaca-przy-zespole-szkol-im-bl-ks-piotra-dankowskiego-w-jordanowie; https://www. facebook.com/technikumekonomiczne), „Ekonomik” w Zespole Szkół Zawodowych im. Adama Chętnika w Ostrołęce (por. http:// 
zsz4.ostroleka.edu.pl/foldery/ekonomik/index.php?menu=1), „Pychotka” w Zespole Szkół Specjalnych nr 105 w Warszawie (por. https://www.zss105.com.pl/pl/pychotka) oraz „Modraczek” w Zespole Placówek Edukacyjnych w Olsztynie (por. https:// www.facebook.com/Sp\%C3\%B3\%C5\%82dzielnia-Uczniowska-MODRAczeK-904305449739092), „Winien-ma” w Zespole Szkó1 Hotelarsko-Turystycznych w Zakopanem (por. https://www.facebook.com/WinienMa; https://szkolnafirma.pl/news/spoldzielnia-uczniowska-winien-ma), „Duo” w Zespole Szkół nr 2 Centrum Kształcenia Ustawicznego im. Tadeusza Kościuszki w Pyrzycach (por. http://www.duo.spoldzielniauczniowska.pl/) i „Rockefeller” w Zespole Szkół Ekonomicznych nr 2 im. I. Daszyńskiego w Krakowie (por. https://www.zse-2.krakow.p1/articles.php?article_id=33; https://szkolnafirma.pl/news/spoldzielnia-rockefeller). Dla czterech ostatnich spółdzielni sklepik szkolny stanowi główny rodzaj prowadzonej działalności gospodarczej, chociaż swoją ofertę te spółdzielnie rozszerzają o inne przedsięwzięcia. Należą do nich: pracownia usług gospodarczych Spółdzielni „Modraczek”, kawiarnia i usługi cateringowe w "Winien-ma”, warsztaty kulinarne i savoir-vivre przy stole „Duo”, a także usługi ksero w spółdzielni szkolnej „Rockefeller”.

Inną formę działalności gospodarczej wybrały pozostałe zrzeszenia szkolne. „Nie ma Lipy” w Zespole Szkół im. Jana Pawła II w Lipce (por. https://szkolnafirma.pl/news/spoldzielnia-uczniowska-nie-ma-lipy; https://www.facebook.com/su.nie.ma.lipy) zajmuje się organizowaniem warsztatów o różnej tematyce, prowadzeniem animacji i festynów dla dzieci. „Spółdzielnia uczniowska ZSS Stronie Śląskie” w Zespole Szkół Samorządowych w Stroniu Śląskim (por. https://www.facebook.com/Sp\%C3\%B3\%C5\%82dzielnia-uczniowska-ZSS-Stronie-\%C5\%9A1\%C4\%85skie-562454884180941) prowadzi objazdowy teatr i catering. Spółdzielnia „Vzór” w Zespole Szkół Mechanicznych w Poznaniu (por. https:/www.facebook. com/Przedsi\%C4\%99biorczo\%C5\%9B\%C4\%87-ZSM-im-KEN-Sp\%C3\%B3\%C5\%82dzielnia-Vz\%C3\%B3r-i-Ekonomia-Spo\%C 5\%82eczna-327714174100121/) organizuje imprezy. Spółdzielnia „Plastusie” w Zespole Szkół Informatycznych w Słupsku (por. http:// plastyk.slupsk.p1/?spoldzielnia-uczniowska-plastusie-,721; https:// www.facebook.com/110055859016867/posts/2002687136420387/) zajmuje się tworzeniem i sprzedażą obrazów, rzeźb oraz projektami 
rysunków umieszczanych na koszulkach. Spółdzielnia „Punkt Ksero ZSŁ” w Zespole Szkół Łączności im. Obrońców Poczty Polskiej w Gdańsku (por. http://www.zsl.gda.pl/aktualnosci/show/spoldzielnia-uczniowska-punkt-ksero-zsl) świadczy usługi ksero, natomiast spółdzielnia uczniowska „Omnia” w IV Liceum Ogólnokształcącym im. Jana Pawła II w Tarnowie (http://www.iv-lo.tarnow.p1/liceum2/ index.php?option $=$ com_content $\& v i$ iew $=$ article $\& i d=1255 \&$ Item id=296) nie umieściła na stronie internetowej informacji o formach swojej działalności.

Rodzaj działalności gospodarczej spółdzielni uczniowskiej rzutuje na zasób informacji zamieszczanych na witrynie internetowej i na formę ich udostępniania. Każda z analizowanych stron przekazuje komunikat o pracy i sposobach działania młodych spółdzielców. Obszerne komunikaty dotyczące zakresu prowadzonej działalności przedstawia spółdzielnia uczniowska „Nie ma Lipy”, która zamieszcza na stronach internetowych wiadomości o codziennej pracy, organizacji akcji charytatywnych dla mieszkańców swojej gminy i uczniów szkoły, wydawania gazetki szkolnej, organizowania imprez dla młodzieży i dorosłych. Oprócz opisu, praca tej spółdzielni uczniowskiej jest dokumentowana materiałami fotograficznymi (por. https://www.facebook.com/su.nie. ma.lipy; https://szkolnafirma.pl/news/spoldzielnia-uczniowska-nie-ma-lipy). Podobne witryny internetowe prowadzą: Spółdzielnia „Duo” (http://www.duo.spoldzielniauczniowska.pl/index.php/o-spoldzielni) i „Spółdzielnia Uczniowska ZSS Stronie Śląskie”, które dokumentują efekty swojej pracy i udział w akcjach charytatywnych za pomocą krótkich tekstów oraz materiału ilustracyjnego (por. https:// www.facebook.com/Sp\%C3\%B3\%C5\%82dzielnia-uczniowska-ZSS-Stronie-\%C5\%9A1\%C4\%85skie-562454884180941).XSpó1dzielnia „Vzór”opisuje i zamieszcza zdjęcia z podejmowanych różnych inicjatyw (akcje charytatywne, targi edukacyjne, warsztaty) oraz prezentuje plan swojej pracy (por. http://zsken.pl/?page_id=2314). Spółdzielnia „Winien-ma” zrezygnowała z materiałów wizualnych, jedynie opisuje swoje działania, wskazując ich zalety dotyczące rozwijania umiejętności ekonomicznych (por. https://szkolnafirma.pl/news/ spoldzielnia-uczniowska-winien-ma). W podobny sposób stronę internetową prowadzi Spółdzielnia „Rockefeller” (https://www.zse-2. krakow.pl/articles.php?article_id=33; https://szkolnafirma.pl/news/ spoldzielnia-rockefeller). Spółdzielnia „Modraczek”, która prowadzi 
sklepik szkolny i przygotowuje dania do sprzedaży, co tydzień zamieszcza menu wraz z opisem używanych produktów. Codziennie pojawiają się zdjęcia przygotowanych dań czy napojów gotowych do sprzedaży (por. https://www.facebook.com/Sp\%C3\%B3\%C5\%82dzielnia-Uczniowska-MODRAczeK-904305449739092). W tej samej kategorii (organizacje spółdzielcze w szkołach ponadpodstawowych) formalnie $\mathrm{w}$ formie opisu (statut, struktura, plan pracy) swoje działania prezentują: „Szarotka” (por. https://zsdjordanow.iap.pl/spoldzielnia-uczniowska-szarotka) oraz „Omnia” (por. http://www.iv-lo.tarnow. p1/liceum2/index.php?option=com_content\&view=article\&id=1255 \&Itemid=296). Spółdzielnia „Pychotka” umieściła na swojej witrynie prezentację multimedialną, wzbogacając opisane informacje zdjęciami (por. https://www.zss105.com.p1/images/pdf/SUPychotka.pdf). Strona internetowa Spółdzielni „Ekonomik” ma status „W budowie” (por. http://zsz4.ostroleka.edu.pl/foldery/ekonomik/zarzad.php). Spółdzielnia „Plastusie” publikuje efekty swojej pracy, czyli obrazy, rzeźby w formie wizualnej, bez opisu (por. http://plastyk.slupsk. pl/?spoldzielnia-uczniowska-plastusie-,721). Podobnie robi Spó1dzielnia „Punkt Ksero ZSŁ”, która zamieszcza na stronie internetowej galerię zdjęć z obrad walnego zgromadzenia (por. http://www.zsl.gda. $\mathrm{pl}$ /aktualnosci/show/spoldzielnia-uczniowska-punkt-ksero-zsl).

Warto zwrócić uwagę zwłaszcza na informacje zamieszczone na stronach internetowych, które dotyczą szerzenia idei spółdzielczej. Okazuje się, że działalność spółdzielni uczniowskich podlega takim samym zasadom, jak działalność spółdzielni prowadzonych przez osoby dorosłe. Oznacza to, że zrzeszenia szkolne funkcjonują na wzór spółdzielni prowadzonych przez dorosłych, czyli przyjmują takie same struktury i zasady funkcjonowania oparte na statutach i organach spó1dzielni. Ponadto jednym z zadań zrzeszeń szkolnych jest konieczność propagowania spółdzielczości uczniowskiej w środowisku szkolnym i pozaszkolnym, co odbywa się m.in. poprzez umieszczanie dokumentów własnej organizacji szkolnej na stronach internetowych. Tak uczyniła Spółdzielnia „Duo”, która na stronie internetowej zamieściła skan statutu, opis organów spółdzielni: Walnego Zgromadzenia, Rady Nadzorczej, Zarządu Spółdzielni wraz z ich uczestnikami oraz logo „spółdzielców dorosłych”, z którymi uczniowie współpracuja (por. http://www.duo.spoldzielniauczniowska.pl/index.php/statut-spoldzielni; http://www.duo.spoldzielniauczniowska.pl/index.php/ 
wladze-i-czlonkowie; http://www.duo.spoldzielniauczniowska.pl/ index.php/partnerzy-spoldzielni). Podobnie Spółdzielnia „Vzór” umieściła teksty i ilustracje obrazujące współpracę z Poznańską Spółdzielnią Spożywców „Społem”, Fundacją Rozwoju Spółdzielczości Uczniowskiej (FRSU) w Krakowie, ze społecznością szkolną i sympatykami spółdzielczości (por. http://zsken.p1/wp-content/uploads/2021/03/Plan-pracy-SU-VZ\%C3\%93R-2019-20.pdf; https:// www.facebook.com/Przedsi\%C 4\%99biorczo\%C5\%9B\%C4\%87-ZSM-im-KEN-Sp\%C3\%B3\%C5\%82dzielnia-Vz\%C3\%B3r-i-Ekonomia-Spo\%C5\%82eczna-327714174100121/). W tym samym tonie wypowiedziała się spółdzielnia „Winien-ma”, która zaprezentowała swój udział w konkursach organizowanych przez FRSU oraz współpracę ze Spółdzielnią Spożywców „Społem” w Zakopanem. W formie opisowej i wizualnej przedstawiła swoją strukturę oraz historię działalności (por. https://www.facebook.com/WinienMa; http://zsht.pl/su/nasi-spoldzielcy/; http://zsht.pl/su/sukcesy/; http:// zsht.pl/su/historia/). Członkowie Spółdzielni „Rockefeller” zawarli informacje dotyczące udziału we współzawodnictwach FRSU i Krajowej Rady Spółdzielczej (KRS) (por. https://www.zse-2.krakow. pl/articles.php?article_id=33). Zrzeszenie uczniowskie „Pychotka” zaprezentowało swoje władze i sukcesy we współpracy z FRSU i KRS oraz Warszawską Spółdzielnią Spożywców Śródmieście „Społem” $\mathrm{w}$ formie opisu i prezentacji skanów otrzymanych dyplomów (por. https://www.zss105.com.pl/pl/pychotka/266-walne-zgromadzenie-cz\%C5\%82onk\%C3\%B3w-su-pychotka; https://www.zss105.com. $\mathrm{pl} / \mathrm{pl} /$ pychotka/274-puchar). Umieszczanie na stronie internetowej dyplomów nadanych przez FRSU i KRS stało się tradycją Spółdzielni „Ekonomik”, która utworzyła zakładkę zatytułowaną „Kronika”, ukazującą $\mathrm{w}$ formie notatki i fotografii (plik do pobrania) minione lata swojej działalności (por. http://zsz4.ostroleka.edu.pl/foldery/ ekonomik/index.php?menu=1; http://zsz4.ostroleka.edu.p1/foldery/ekonomik/pliki/Kronika2018-2019.pdf; http://zsz4.ostroleka. edu.pl/foldery/ekonomik/pliki/Kronika2018-2019czII.pdf; http:// zsz4.ostroleka.edu.pl/foldery/ekonomik/kronika.php). Podobnie Spółdzielnia "Szarotka” opisuje swoje sukcesy związane z organizowanymi przez FRSU i KRS inicjatywami oraz przedstawia władze swojej spółdzielni (por. http://zsdjordanow.iap.pl/spoldzielnia-uczniowska-szarotka/aktualnosci-1; https://zsdjordanow.iap.pl/ 
spoldzielnia-uczniowska-szarotka). Tak samo uczyniła spółdzielnia uczniowska „Nie ma Lipy” (por. https://www.facebook.com/su.nie. ma.lipy).

Młodzi spółdzielcy ze szkół średnich na swoich stronach internetowych przekazują informacje o spędzaniu w różnych formach czasu wolnego, co jest możliwe dzięki wypracowanym przez nich środkom finansowym. To informacja o tym, że członkostwo w spółdzielni uczniowskiej nie polega tylko na pracy czy pomocy innym, ale również przynosi różne profity. Są to wycieczki, imprezy i wspólne spędzanie czasu w grupie spółdzielców podczas posiłków, co przedstawiają opisy ze zdjęciami prezentowane przez spółdzielnie: „Nie ma Lipy”(por. https://www.facebook.com/su.nie.ma.lipy), ,Winien-ma” (por. http://zsht.pl/su/category/wyjazdy/; http://zsht.pl/su/category/wyjazdy/page/2/; https://www.facebook.com/WinienMa), „Duo” (por. http://www.duo.spoldzielniauczniowska.pl/index.php/ aktualnosci), „Szarotki” (por. http://zsdjordanow.iap.pl/spoldzielnia-uczniowska-szarotka/wycieczki), „Ekonomika” (por. http://zsz4. ostroleka.edu.pl/foldery/ekonomik/index.php?menu=3; http://zsz4. ostroleka.edu.pl/foldery/ekonomik/index.php?menu=4; http://zsz4 . ostroleka.edu.pl/foldery/ekonomik/index.php?menu=5; http://zsz4. ostroleka.edu.pl/foldery/ekonomik/index.php?menu=6), „Pychotki" (por. https://www.zss105.com.pl/pl/pychotka/276-andrzejki; https://zss105.com.pl/images/pdf/SUPychotka.pdf). Same opisy wspólnie spędzanego czasu wolnego zawiera witryna Spółdzielni „Rockefeller” (por. https://szkolnafirma.pl/news/spoldzielnia-rockefeller). „Spółdzielnia Uczniowska ZSS Stronie Śląskie” uzupełnia swoje informacje filmem poświęconym zasadom bezpieczeństwa podczas spędzania czasu wolnego (por. https://www.facebook.com/ Sp\%C3\%B3\%C5\%82dzielnia-uczniowska-ZSS-Stronie-\%C5\%9 Al\%C4\%85skie-562454884180941/). Zdjęcia, opis i film poświęcone wspólnej organizacji czasu wolnego prezentują spółdzielcy zrzeszenia uczniowskiego „Vzór” (por. https://www.facebook. com/Przedsi\%C4\%99biorczo\%C5\%9B\%C4\%87-ZSM-im-KEN-Sp\%C3\%B3\%C5\%82dzielnia-Vz\%C3\%B3r-i-Ekonomia-Spo\%C 5\%82eczna-327714174100121/). Takiej informacji nie umieszczają na swoich stronach internetowych spółdzielnie: „Omnia”, „Punkt Ksero ZSE” i „Modraczek”. 


\section{Funkcje popularno-towarzyskie witryn internetowych spółdzielni uczniowskich}

Dalsze badania stron internetowych spółdzielni uczniowskich w szkołach ponadpodstawowych skoncentrowały się na analizie działalności towarzyskiej ukazywanej w Internecie przez spółdzielnie uczniowskie. Wszystkie zrzeszenia posiadające własne strony internetowe na Facebooku, czyli „Modraczek” (por. https:// www.facebook.com/Sp\%C3\%B3\%C5\%82dzielnia-Uczniowska-MODRAczeK-904305449739092), „Winien-ma” (por. https://www.facebook.com/WinienMa), „Spółdzielnia Uczniowska ZSS Stronie Śląskie" (por. https://www.facebook.com/ Sp\%C3\%B3\%C5\%82dzielnia-uczniowska-ZSS-Stronie-\%C5\%9A1 \%C4\%85skie-562454884180941), „Nie ma Lipy” (por. https://www. facebook.com/su.nie.ma.lipy), „Vzór” (por. https://www.facebook. com/Przedsi\%C4\%99biorczo\%C5\%9B\%C4\%87-ZSM-im-KEN-Sp\%C3\%B3\%C5\%82dzielnia-Vz\%C3\%B3r-i-Ekonomia-Spo\% C5\%82eczna-327714174100121/), „Szarotka” (por. https://www. facebook.com/dankowskijordanow) oraz „Plastusie” (por. https:// www.facebook.com/110055859016867/posts/2002687136420387/), używają czatu jako podstawowej formy komunikacji. Istnieje również możliwość napisania wiadomości do spółdzielni uczniowskiej przez osoby z nią niezrzeszone („Wyślij wiadomość). Kolejnym udogodnieniem, jeśli chodzi o wymiar towarzyski, dostępnym na Facebooku jest funkcja umożliwiająca gromadzenie znajomych („Szukaj znajomych”, „Oznacz znajomych”, „Zaproś znajomych”), pozwalająca na zawieranie i utrzymywanie znajomości.

Inaczej natomiast wygląda kwestia zawierania kontaktów towarzyskich za pośrednictwem własnych stron internetowych prowadzonych przezspółdzielnie uczniowskie.Własnego mailaudostępniłytylkozrzeszenie „Duo” (por. http://www.duo.spoldzielniauczniowska.pl/index. php/kontakt-z-nami) oraz „Winien-ma” (por. https://www.facebook. com/WinienMa). Spółdzielnie „Ekonomik” (por. http://zsz4.ostroleka.edu.pl/foldery/kontakt/index.php),„Omnia”(por.http://www.iv-lo. tarnow.pl/liceum $2 /$ index.php?option $=$ com_content\&view $=$ article $\&$ id=155\&Itemid=136) i „Rockefeller” (por. https://www.zse-2.krakow.pl/viewpage.php?page_id=23) nie podają żadnych informacji dotyczących możliwości kontaktu ze spółdzielcami, ale udostępniają 
kontakt ze szkołą, w której działają. Spółdzielnia „Punkt Ksero ZSŁ” (por.http://www.zsl.gda.pl/kontakt/) umożliwia taki sposób komunikacji za pomocą formularza kontaktowego, a „Pychotka” (por. https:// www.zss105.com.p1/pl/pychotka) nie informuje wcale o możliwości jakiegokolwiek kontaktu ze spółdzielcami.

O popularności spółdzielni uczniowskich w Internecie świadczą głównie trzy czynniki. Pierwszy z nich to pozycja, na której wyświetla się dana strona w wyszukiwarce, drugi - liczba postów i komentarzy umieszczanych na witrynie internetowej, a trzeci - liczba „lajków” i udostępnień.

Rodzaj komunikacji zależy od posiadanej przez spółdzielnię uczniowską witryny internetowej oraz od jej możliwości. Portal społecznościowy Facebook proponuje nie tylko umieszczanie informacji, ale również udostępnia platformę komunikacyjną w postaci czatu. Dzięki niemu młodzi ludzie mogą ze sobą rozmawiać w dowolnym czasie oraz śledzić swój status dostępności/gotowości do rozmowy. To pozwala na szybki przekaz informacji, wpływając m.in. na relacje między spółdzielcami, którzy mogą być w ciągłym kontakcie. Kontakt za pośrednictwem Facebooka proponują 4 spółdzielnie uczniowskie („Modraczek”, „Spółdzielnia Uczniowska w Stroniu Sląskim”, „Nie ma Lipy”, „Winien-ma”). Kontakt „przez szkołę”, w której funkcjonuje zrzeszenie, podaje 6 spółdzielni uczniowskich („Vzór”, ,Szarotka”, „Plastusie”, „Ekonomik”, „Omnia”, „Rockefeller”), adres e-mail udostępniają dwie spółdzielnie („Winien-ma”, „Duo”), jedno zrzeszenie uczniowskie udostępnia formularz kontaktowy („Punkt Ksero ZSE”), a żadnej platformy umożliwiającej kontakt nie udostępnia tylko jedna spółdzielnia uczniowska („Pychotka”).

Podczas wymiany informacji i/lub przekazu wiadomości na witrynach internetowych, bez oczekiwania na informację zwrotną, młodzi ludzie używają w swoich tekstach emotikonów wyrażających nastrój. Dostrzec je można np. w opisach, komentarzach oraz pod filmem przedstawiającym efekty prac kulinarnych w Spółdzielni „Szarotka” (por. https://www.facebook.com/dankowskijordanow). Są to uśmiechnięte buzie. Na Facebooku Spółdzielni „Modraczek” można trafić na uśmiechnięte twarze, buźki wskazujące na pyszne dania („pycha”) oraz kciuki wskazujące ku górze (por. https://www.facebook.com/Sp\%C3\%B3\%C5\%82dzielnia-Uczniowska-MODRAczeK-904305449739092). Podobnie jest na 
Facebooku Spółdzielni „Winien-ma” (por. https://www.facebook. com/WinienMa) oraz „Nie ma Lipy”, choć tam pojawia się jeszcze emotikonek oznaczający zwycięstwo (por. https://www.facebook. com/su.nie.ma.lipy). Na Facebooku Spółdzielni „Vzór” gamę emotikonów uzupełnia symbol zdziwienia (por. https://www.facebook. com/Przedsi\%C4\%99biorczo\%C5\%9B\%C4\%87-ZSM-im-KEN-Sp\%C3\%B3\%C5\%82dzielnia-Vz\%C3\%B3r-i-Ekonomia-Spo \%C5\%82eczna-327714174100121/). Na facebookowym serwisie społecznościowym „Spółdzielni Uczniowskiej ZSS Stronie Śląskie" dominują serca, buźki z oczami w kształcie serca, symbol siły i masek teatralnych oraz emotikony przedstawiające jedzenie (ciastko, ciasto, kanapka) (por. https://www.facebook.com/ Sp\%C3\%B3\%C5\%82dzielnia-uczniowska-ZSS-Stronie-\%C5\%9 A1\%C4\%85skie-562454884180941). Inne spółdzielnie, np.: „Plastusie" (por. http://plastyk.slupsk.p1/?spoldzielnia-uczniowska-plastusie-,721; https://www.facebook.com/110055859016867/ posts/2002687136420387/), „Ekonomik” (por. http://zsz4.ostroleka.edu.pl/foldery/ekonomik/index.php?menu=2), „Duo” (por. http://www.duo.spoldzielniauczniowska.pl/), „Omnia” (por. http:// www.iv-lo.tarnow.pl/liceum2/index.php?option=com_content\&vi ew=article\&id=1255\&Itemid=296), „Pychotka” (por. https://www. zss105.com.pl/p1/pychotka), „Punkt Ksero ZSE” (por. http://www. zsl.gda.pl/aktualnosci/show/spoldzielnia-uczniowska-punkt-ksero-zsl) oraz „Rockefeller” (por. https://www.zse-2.krakow.pl/articles. php?article_id=33) na swoich stronach internetowych nie posługują się żadnymi emotikonami.

Biorąc pod uwagę liczbę używanych emotikonów na witrynach internetowych przez młodych spółdzielców ze szkół ponadpodstawowych, można sformułować wniosek, że taka aktywność ma charakter pozytywny, o czym świadczą zamieszczane symbole. Służą one jako uzupełnienie i/lub urozmaicenie tekstu, wzbogacając go o wymiar emocjonalny. Używane są przez spółdzielców (6 spółdzielni uczniowskich) korzystających z opisywanego portalu społecznościowego. Pozostali spółdzielcy (7 spółdzielni uczniowskich) komunikują się przez strony internetowe stosując sam tekst. Zatem kategoria wymiany informacji jest zmediatyzowana. 


\section{Podsumowanie}

W dobie zmediatyzowanej komunikacji witryny internetowe spółdzielni uczniowskich odgrywają ważną rolę i stanowią główną formę przekazu informacji dla środowiska spółdzielczego, lokalnego, szkolnego i pozaszkolnego. Ze względu na dostępność, popularność i brak opłat za użytkowanie zrzeszenia uczniowskie najczęściej do tego celu wybierają portal społecznościowy Facebook. Nierzadko wspierają się stronami internetowymi szkół, w których funkcjonują, aby uatrakcyjnić ofertę placówki i udostępnić szerszemu gronu odbiorców efekty swojej działalności. Ponadto korzystają z witryn w sieci: www.szkolnafirma.pl, reklamującej i zachęcającej do zakładania tego rodzaju zrzeszeń, oraz www.school\&collegelisttings.com, będącej uzupełnieniem dla jednej z nich. Tylko jedna spółdzielnia uczniowska („Duo”w Zespole Szkół nr 2 Centrum Kształcenia Ustawicznego im. Tadeusza Kościuszki w Pyrzycach) podsiada własną stronę internetową.

Analiza witryn internetowych spółdzielni uczniowskich funkcjonujących w szkołach ponadpodstawowych pozwoliła wyodrębnić ich funkcje informacyjno-edukacyjne oraz popularno-towarzyskie. Strony internetowe spółdzielni uczniowskich przekazują różne wiadomości dla szerokiego kręgu odbiorców. W każdej z nich głównym przekazem jest rodzaj działalności oraz związane z nim powinności i wynikające stąd korzyści. Informują i edukują o rodzaju prowadzonej działalności gospodarczej spółdzielni uczniowskiej i jej ofercie, o efektach swojej pracy, zamieszczają informacje o inicjatywach pomocowych, o spotkaniach spółdzielczych czy o wytworzonych rękodziełach. Popularyzują ideę spółdzielczości opartą na współpracy, współdziałaniu i wzajemnej pomocy. Nawiązują do założeń ruchu spółdzielczego prowadzonego przez osoby dorosłe, przyjmując od nich wypracowane i sprawdzone struktury, zasady funkcjonowania, organy i sposób prowadzenia dokumentacji. Dzięki temu witryny internetowe pełnią funkcję edukacyjną, polegająca na zapoznawaniu czytelników z założeniami ruchu spółdzielczości uczniowskiej oraz ukazywaniu jego wartości wychowawczych, w tym wypracowanych umiejętności z zakresu przedsiębiorczości, pracy w organizacji uczniowskiej i innych. Interesującym elementem witryn internetowych zrzeszeń uczniowskich są wpisy dotyczące spędzania czasu wolnego 
po pracy w spółdzielni lub w czasie wakacji. Organizacja czasu wolnego młodych spółdzielców zależy od ich pomysłowości i możliwości finansowych uzyskanych z działalności gospodarczej zrzeszenia. Młodzi spółdzielcy na stronach internetowych informują o organizowaniu dla siebie wyjazdów krajowych i zagranicznych, urządzaniu tematycznych spotkań towarzyskich i innych form spędzania czasu wolnego oraz o przyznawaniu nagród dla spółdzielców za roczną pracę.

Wymiar edukacyjny stanowi wspólny mianownik wszystkich witryn internetowych spółdzielni uczniowskich w szkołach ponadpodstawowych, niezależnie od wyboru sposobu przekazywania informacji. Każda spółdzielnia kieruje informacje do różnych odbiorców w sposób pośredni lub bezpośredni w kontekście edukacyjnym. Funkcja edukacyjna przejawia się w sposób pośredni przede wszystkim w umiejętnościach członków spółdzielni prowadzących witryny internetowe, które dotyczą: zakładania witryny internetowej i jej prowadzenia, prowadzenia zakładki na stronie internetowej szkoły, w której funkcjonuje zrzeszenie uczniowskie, współpracy i współdziałania między sobą, społecznością szkolną i pozaszkolną, aktualizowania treści witryn spółdzielczych, do czego są potrzebne umiejętności organizacyjne, pracowitość i samodyscyplina. Funkcja edukacyjna przejawia się również w sposób bezpośredni, o czym świadczy dająca się zauważyć na stronach internetowych kreatywność, zaangażowanie, rozwijanie różnych umiejętności przez członków spółdzielni uczniowskich, o czym świadczy ich działalność gospodarcza, znajomość zasad działania spółdzielni, reklamowanie swojej spółdzielni uczniowskiej, prezentowanie sposobów spędzania czasu wolnego, propagowanie edukacji medialnej, udział w akcjach charytatywnych i inne przejawy działalności młodych spółdzielców.

Witryny internetowe pełnią również funkcje popularno-towarzyskie. Przeprowadzone analizy dowiodły, że korzystanie z czatu na Facebooku jest najbardziej popularnym sposobem nawiązywania kontaktów przez spółdzielców. Drugą formą kontaktu wybieraną przez członków spółdzielni uczniowskich jest udostępnianie adresu mailowego szkoły, rzadziej adresu mailowego spółdzielni uczniowskiej. Do tego celu wykorzystywany jest też formularz kontaktowy. Żadne z analizowanych zrzeszeń szkolnych nie umieszcza na swoich witrynach internetowych numeru telefonu kontaktowego. Trzeba zaznaczyć, że komunikaty zawarte na witrynach internetowych są 
kierowane do różnych odbiorców, nie tylko do członków spółdzielni, ale także do całej społeczności szkolnej i pozaszkolnej. Analizowane witryny internetowe nie były zablokowane czy udostępniane tylko dla konkretnej grupy. Są one dostępne dla każdego użytkownika sieci. Informacje przekazywane są zwykle w postaci opisu i fotografii oraz prezentacji multimedialnych czy filmów opatrzonych emotikonami i/lub komentarzami.

Podsumowując, można wysnuć wniosek, że witryny internetowe spółdzielni uczniowskich w szkołach ponadpodstawowych, pełniąc funkcje informacyjno-edukacyjne i popularno-towarzyskie, prezentują w zasadzie podobne informacje. Przedstawiają codzienną pracę młodych spółdzielców, ich udział w różnych imprezach, warsztatach czy akcjach charytatywnych oraz ukazują sposób organizacji własnego czasu wolnego. Tym, co odróżnia te witryny od siebie, jest sam sposób przekazu wiadomości. Dostrzegalne są również różnice w objętości przekazywanych informacji i w pewnym stopniu także w samej treści. Jeśli chodzi o formę przekazu, to polega ona na opisie podejmowanych działań gospodarczych, edukacyjnych i społeczno-kulturalnych $\mathrm{i} /$ lub dokumentowaniu ich $\mathrm{w}$ formie zdjęć bądź prezentacji multimedialnych.

Strony internetowe zrzeszeń uczniowskich popularyzują spółdzielczość uczniowską, zachęcają do dołączenia w swoje szeregi, reklamują własną działalność oraz wskazują na zalety takich organizacji uczniowskich w szkołach ponadpodstawowych. Witryny internetowe stały się wirtualnymi i łatwo dostępnymi wizytówkami spółdzielni uczniowskich. Biorąc pod uwagę fakt, że zmediatyzowana rzeczywistość wymusza rozumienie i świadome użytkowanie przestrzeni wirtualnej, należy zaznajamiać uczniów i ich rodziców z funkcjami i znaczeniem witryn internetowych oraz ich właściwym wykorzystaniem.

\section{Bibliografia}

Adler B.R., Rosenfeld B.L., Proctor II F.R. (2018). Relacje interpersonalne. Proces porozumiewania się, przeł. G. Skoczylas, wyd. 3, Poznań: Dom Wydawniczy Rebis.

Aouil B. (2008). Komunikowanie się w Internecie - narzędzia, specyfika i wtaściwości, [w:] Komunikacja spoteczna w świecie wirtualnym, red. M. Wawrzak-Chodaczek, Toruń-Wrocław: Wydawnictwo Adam Marszałek, Instytut Pedagogiki Uniwersytetu Wrocławskiego, s. 26-28. 
Bębas S., Plis J., Bednarek J. (2012). Wprowadzenie, [w:] Komunikacja w cyberśrviecie, red. S. Bębas, J. Plis, J. Bednarek, Radom: Wyższa Szkoła Handlowa w Radomiu, s. 11.

Bochnia B., Bochnia K. (2010). Ukryty program w komunikacji niewerbalnej, [w:] Komunikowanie spoteczne w edukacji. Zagrożenia podmiotowe i psychospoteczne, red. K. Czerwiński, M. Fiedor,J. Kubiczek, Toruń: Wydawnictwo Adam Marszałek, s. 60-61.

Goban-Klas T. (2005). Cywilizacja medialna. Geneza, ewolucja, eksplozja, Warszawa: Wydawnictwa Szkolne i Pedagogiczne.

Huk T. (2012). Zjawisko satanizmu w dziecięcych i mtodzieżowych blogach internetowych, [w:] Cyberprzestrzeń i edukacja, red. T. Lewowicki, B. Siemienicki, Toruń: Wydawnictwo Adam Marszałek, s. 335-353.

Huk T. (2014). Pedagogika medialna. Aspekty spoteczne, kulturowe i edukacyjne, Kraków-Katowice: Oficyna Wydawnicza „Impuls”.

Hyb L. (2012). Informacja jako czynnik wspótczesnej edukacji, [w:] Komunikacja w cyberświecie, red. S. Bębas, J. Plis, J. Bednarek, Radom: Wyższa Szkoła Handlowa w Radomiu.

Izdebska J. (2002). Dzieci "globalnej wioski” - nowy wymiar dziecinstwa. Wyzwania pedagogiczne, [w:] Media i edukacja w dobie integracji, red. W. Strykowski, W. Skrzydlewski, Poznań: Wydawnictwo Naukowe UAM w Poznaniu.

Jemielniak D. (2019). Socjologia Internetu, Warszawa: Wydawnictwo Naukowe Scholar.

Kania J. (2018). Nauczyciele wobec potrzeb stosowania nowych technologii informacyjno-komunikacyjnych w procesie dydaktycznym, „Edukacja Humanistyczna”, nr 2(39), s. 7-16.

Łęski Z., Wieczorek Z. (2004). Internet: informacja czy relacja?, [w:] Oblicza Internetu, red. M. Sokołowski, Elbląg: Wydawnictwo Państwowej Wyższej Szkoły Zawodowej, s. 53-67.

Łobocki M. (2009). Metody i techniki badań pedagogicznych, Kraków: Oficyna Wydawnicza „Impuls”, s. 28-31.

Magiera E. (2011a). Spótdzielczośc jako forma edukacji w szkolnictwie polskim Drugiej Rzeczypospolitej, Szczecin: Wydawnictwo Naukowe Uniwersytetu Szczecińskiego.

Magiera E. (2011b). Wspótpraca rodziny i szkoty w wychowaniu spótdzielczym dzieci i mtodzieży w Drugiej Rzeczypospolitej (1918-1939), „Wychowanie w Rodzinie", t. 2, s. 107-123.

Magiera E. (2014). Przysposobienie spótdzielcze wiejskiej mtodzieży pozaszkolnej w Polsce w okresie międzywojennym (1917-1939), „Wychowanie w Rodzinie”, t. 10, s. 103-104.

Magiera E. (2016). Zarys rozwoju ruchu spótdzielczego na ziemiach polskich pod zaborem pruskim w drugiej potowie XIX i na poczqtku XX wieku oraz jego edukacyjny charakter, „Studia Pedagogica Ignatiana”, t. 19, nr 3, s. 183-197. 
Magiera E. (2019). Podstawy formalno-prawne dziatalności spótdzielni uczniowskich w Polsce w latach 1945-1989, [w:] Zatożenia i realizacja ustroju szkolnego w Polsce w latach 1945-1989 (wybrane aspekty), red. B. Walak, Gorzów Wielkopolski: Akademia im. Jakuba z Paradyża w Gorzowie Wielkopolskim, s. 63-90.

Morbitzer J. (2009). O potrzebie edukacji medialnej, „Wychowawca”, nr 9, s. 5-7,

Olechnicki K., Załęcki P. (1999). Stownik socjologiczny, Toruń: Wydawnictwo Graffiti BC.

Polak R. (2008). Poczatek rewolucji w komunikacji lokalnej? Realne a wirtualne media lokalne, [w:] Komunikacja w świecie wirtualnym, red. M. Wawrzak-Chodaczek, Toruń: Wydawnictwo Adam Marszałek.

Silverman D. (2012). Interpretacja danych jakościowych. Metody analizy rozmowy, tekstu i interakcji, przeł. M. Głowacka-Grajper, J. Ostrowska, Warszawa: Wydawnictwo Naukowe PWN.

Sokołowski M. (2013). Nowe media: konwergencja technologiczna i rozszerzenie praktyk komunikacyjnych, [w:] Nowe media $i$ wyzwania wspótczesności, red. M. Sokołowski, Toruń: Wydawnictwo Adam Marszałek.

Strykowski W., Skrzydlewski W. (2002). Przedmowa, [w:] Media i edukacja $w$ dobie integracji, red. W. Strykowski, W. Skrzydlewski, Poznań: Wydawnictwo eMPi2, s. 7-8.

Świtalski Z. (1985). Historia spótdzielczości uczniorwskiej w Polsce w latach 1900-1985, Warszawa: Naczelna Rada Spółdzielcza.

\section{Netografia}

http://www.duo.spoldzielniauczniowska.pl/ [dostęp: 16.03.2021].

http://www.duo.spoldzielniauczniowska.pl/index.php/aktualnosci [dostęp:

22.03.2021].

http://www.duo.spoldzielniauczniowska.pl/index.php/kontakt-z-nami [dostęp: 23.03.2021].

http://www.duo.spoldzielniauczniowska.pl/index.php/o-spoldzielni [dostęp: 22.03.2021].

http://www.duo.spoldzielniauczniowska.pl/index.php/partnerzy-spoldziel-

ni [dostęp: 22.03.2021].

http://www.duo.spoldzielniauczniowska.pl/index.php/statut-spoldzielni [dostęp: 22.03.2021].

http://www.duo.spoldzielniauczniowska.pl/index.php/wladze-i-czlonkowie [dostęp: 22.03.2021].

http://www.frsu.pl/uploads/attachments/9eb4dc8ac519e221fde3540cc66cd 6fa.pdf [dostęp: 22.03.2021].

http://www.iv-lo.tarnow.pl/liceum2/index.php?option=com_content\&view $=$ article\&id=1255\&I temid=296 [dostęp: 16.03.2021] . 
http://www.iv-lo.tarnow.p1/liceum2/index.php?option=com_content\&view

$=$ article\&id=155\&Itemid=136 [dostęp: 23.03.2021].

http://www.zsl.gda.pl/aktualnosci/show/spoldzielnia-uczniowska-punkt-ksero-zsl [dostęp: 24.03.2021].

http://www.zsl.gda.pl/kontakt/ [dostęp: 23.03.2021].

http://zsdjordanow.iap.pl/spoldzielnia-uczniowska-szarotka/aktualnosci-1

[dostęp: 16.03.2021].

http://zsdjordanow.iap.pl/spoldzielnia-uczniowska-szarotka/wycieczki

[dostęp: 22.03.2021].

http://zsht.pl/su/category/wyjazdy/ [dostęp: 22.03.2021].

http://zsht.pl/su/category/wyjazdy/page/2/ [dostęp: 22.03.2021].

http://zsht.pl/su/historia/ [dostęp: 22.03.2021].

http://zsht.pl/su/nasi-spoldzielcy/ [dostęp: 22.03.2021].

http://zsht.pl/su/sukcesy/ [dostęp: 22.03.2021].

http://zsken.pl/?page_id=2314 [dostęp: 22.03.2021].

http://zsken.pl/wp-content/uploads/2021/03/Plan-pracy-SU-VZ\%C3\%

93R-2019-20.pdf [dostęp: 22.03.2021].

http://zsz4.ostroleka.edu.pl/foldery/ekonomik/index.php?menu=1 [dostęp:

16.03.2021].

http://zsz4.ostroleka.edu.p1/foldery/ekonomik/index.php?menu=2 [dostęp:

24.03.2021].

http://zsz4.ostroleka.edu.pl/foldery/ekonomik/index.php?menu=3 [dostęp: 22.03.2021].

http://zsz4.ostroleka.edu.p1/foldery/ekonomik/index.php?menu=4 [dostęp:

22.03.2021].

http://zsz4.ostroleka.edu.p1/foldery/ekonomik/index.php?menu=5 [dostęp:

22.03.2021].

http://zsz4.ostroleka.edu.pl/foldery/ekonomik/index.php?menu=6 [dostęp: 22.03.2021].

http://zsz4.ostroleka.edu.pl/foldery/ekonomik/kronika.php [dostęp:

22.03.2021].

http://zsz4.ostroleka.edu.pl/foldery/ekonomik/pliki/Kronika2018-2019.pdf

[dostęp: 22.03.2021].

http://zsz4.ostroleka.edu.pl/foldery/ekonomik/pliki/Kronika2018-

-2019czII.pdf [dostęp: 22.03.2021].

http://zsz4.ostroleka.edu.pl/foldery/ekonomik/zarzad.php [dostęp:

22.03.2021].

http://zsz4.ostroleka.edu.pl/foldery/kontakt/index.php [dostęp:23.03.2021]. https://szkolnafirma.pl/news/spoldzielnia-rockefeller [dostęp: 22.03.2021]. https://szkolnafirma.pl/news/spoldzielnia-uczniowska-nie-ma-lipy [dostęp: 16.03.2021].

https://szkolnafirma.pl/news/spoldzielnia-uczniowska-szarotka-dzialajaca-przy-zespole-szkol-im-bl-ks-piotra-dankowskiego-w-jordanowie [dostęp: 16.03.2021]. 
https://szkolnafirma.pl/news/spoldzielnia-uczniowska-winien-ma [dostęp: 22.03.2021].

https://www.facebook.com/110055859016867/posts/2002687136420387/

[dostęp: 16.03.2021].

https://www.facebook.com/dankowskijordanow [dostęp: 24.03.2021].

https://www.facebook.com/Przedsi\%C4\%99biorczo\%C5\%9B\%C4\%87-

-ZSM-im-KEN-Sp\%C3\%B3\%C5\%82dzielnia-Vz\%C3\%B3r-i-Eko-

nomia-Spo\%C5\%82eczna-327714174100121/ [dostęp: 16.03.2021].

https://www.facebook.com/Sp\%C3\%B3\%C5\%82dzielnia-Uczniowska-

-MODRAczeK-904305449739092 [dostęp: 15.03.2021].

https://www.facebook.com/Sp\%C3\%B3\%C5\%82dzielnia-uczniowska-

-ZSS-Stronie-\%C5\%9A1\%C4\%85skie-562454884180941 [dostęp: 16.03.2021].

https://www.facebook.com/su.nie.ma.lipy [dostęp: 16.03.2021].

https://www.facebook.com/technikumekonomiczne [dostęp: 16.03.2021].

https://www.facebook.com/WinienMa [dostęp: 16.03.2021].

https://www.krs.org.pl/index.php?option=com_content\&view=article\&id=4

1\&Itemid=297) [dostęp: 16.03.2021].

https://www.schooland collegelistings.com/XX/Unknown/9043054

49739092/Sp\%C3\%B3\%C5\%82dzielnia-Uczniowska--MODRAczeK

[dostęp: 16.03.2021].

https://www.zse-2.krakow.pl/articles.php?article_id=33 [dostęp: 22.03.2021]. https://www.zse-2.krakow.pl/viewpage.php?page_id=23 [dostęp:23.03.2021]. https://www.zss105.com.pl/images/pdf/SUPychotka.pdf [dostęp:

22.03.2021].

https://www.zss105.com.pl/p1/pychotka [dostęp: 16.03.2021].

https://www.zss105.com.pl/p1/pychotka/266-walne-zgromadzenie-

-cz\%C5\%82onk\%C3\%B3w-su-pychotka [dostęp: 22.03.2021].

https://www.zss105.com.pl/p1/pychotka/274-puchar [dostęp: 22.03.2021].

https://www.zss105.com.pl/p1/pychotka/276-andrzejki [dostęp:22.03.2021]. https://zsdjordanow.iap.pl/spoldzielnia-uczniowska-szarotka [dostęp:

22.03.2021].

\title{
ADRES DO KORESPONDENCJI
}

\author{
Mgr Aleksandra Joanna Prus \\ Uniwersytet Szczeciński \\ Instytut Pedagogiki \\ e-mail: olaprus@op.pl
}

